\title{
EFFECTS OF AUTOLOG SALIVA ON BIOFILM FORMATION OF STREPTOCOCCUS MUTANS ISOLATED FROM CARIES AND CARIES-FREE SUBJECTS
}

\author{
Felicia Paramita ${ }^{1 *}$, Putri Annika ${ }^{1}$, Endang Winiati Bachtiar ${ }^{2}$, Mindya Yuniastuti $^{2}$ \\ 1. Program of Bachelor of Dental Science, Faculty of Dentistry, Universitas Indonesia \\ 2. Department of Oral Biology, Faculty of Dentistry, Universitas Indonesia \\ *Email: felicia.paramita@gmail.com
}

\begin{abstract}
Saliva and Streptococcus mutans play role in biofilm formation. Saliva and S.mutans virulence are different between subjects with and without caries. Objective: The aim of this study was to evaluate the effects of autolog saliva on biofilm formation of S. mutans isolated from caries and caries-free subjects. Materials and Methods: Saliva and plaque samples are obtained from caries and caries-free subjects. Plaque samples were cultured on TYS20B for 3 days. Selected colonies were picked and cultured on TSB for 3 days. After colony counting, biofilm assay was conducted and inoculated for one day. The biofilm was tested using crystal violet binding assay and quantified by measuring the optical density at 655 $\mathrm{nm}$ wavelength. Result: The optical density of $S$. muttans biofilm isolated from subjects with caries were different from taste with no caries. Biofilm formation of S. muttans isolated from caries and caries-free subjects with and without the presence of autolog saliva were different. Conclusion: Autolog saliva influences S. mutans biofilm formation and there is a tendency that is higher than those from subjects with no caries.
\end{abstract}

Keywords: Streptococcus mutans, biofilm, autolog saliva, caries and caries-free subjects

\section{Introduction}

Caries is the most common disease of the mouth. ${ }^{1}$ Caries occurs when microorganisms adhere to the tooth surface and embedded in extracellular matrix, forming biofilm and produce acid as their metabolism by product. ${ }^{2}$

Biofilm is a diverse microbial community covered on the tooth surface, and composed of extracellular matrix polymers bacterial and salivary origin. ${ }^{3}$ According to ecological plaque hypothesis, a change in a key environmental factor will trigger a shift in the balance of the resident plaque microflora, which would promote the emergence of more cariogenic bacteria, especially Streptococcus mutans and alter the equilibrium toward dental demineralization. ${ }^{4}$

S. mutans is the most significant bacteria in promoting dental caries and can be classified into 7 serotypes. ${ }^{5}$ However, A study by Silva, Cruz and Sampaio (2008) showed that there was no correlation between $S$. mutans count and caries status of individuals. ${ }^{6}$ Since the colony counting did not influence the caries occurrence, people concluded that there must be another factor contributing in caries, as the virulence factors. S.mutans virulence factors are their abilities to produce acid (acidogenic), to survive in acid environment (aciduric) and to adhere on the tooth surface. ${ }^{7,8}$

Antigens of S.mutans that influence virulence factors, are Antigen I/II, Glucosyltransferases and Glucanbinding proteins. ${ }^{9}$ Sucrose-independent adherence is thought to be most profoundly influenced by Antigen $\mathrm{I} / \mathrm{II}$, a $185 \mathrm{kDa}$ surface protein. Salivary agglutinin is served as the receptor of Antigen I/II. ${ }^{10}$ The action of glucosyltransferases (Gtf) in the synthesis of glucans is the major mechanism behind sucrose-dependent adherence. ${ }^{10}$ A study by Khoo et al (2005) showed that $S$. mutans isolated from caries subjects forms more waterinsoluble glucans that play role in the adherence of $S$. mutans. ${ }^{11}$ The glucan-binding proteins are served as the receptor for glucans synthesized by Gtf. ${ }^{10}$ 
Based on all studies explained before, this experiment uses the same principles to study the effects of autolog saliva to biofilm formation of $S$. mutans isolated from caries and caries-free subjects.

\section{Materials and Methods}

This study has been approved by Research Ethical Committee of Faculty (of Dentistry), Universitas Indonesia. Participation in the study is voluntary. The study was carried out at Faculty of Dentistry, Universitas Indonesia. The subjects $(n=30), 15$ of which are caries subjects and the other 15 are caries-free subjects. They were students of this faculty, between 17-23 years old capable to give informed consent, free from terminal and serious illness.

\section{Samples collection}

S. mutans were isolated from buccal area 36 and 46 dental plaque using sterile cotton buds, dispersed into micro centrifuge tubes containing $1 \mathrm{PBS}$ and stored at $4^{\circ} \mathrm{C}$ until used. Unstimulated whole saliva were collected via spitting method into sterile $15-\mathrm{ml}$ tubes. The saliva was centrifuged at $10,000 \times \mathrm{g}, 15$ minutes, in $4^{\circ} \mathrm{C}$ and stored at $-20^{\circ} \mathrm{C}$ prior to use.

\section{Culture of bacteria}

Plaque samples were cultured on TYS20B for 72 hours, after that the colonies were cultured on TSB for another 72 hours. The colony counting was conducted using a microplate reader by measuring the optical density at $655 \mathrm{~nm}$ absorbance length. Bacteria were diluted until $10^{6} \mathrm{CFU} / \mathrm{ml}$ prior to use.

\section{Biofilm formation assays}

Biofilm assays were done using flat bottom 96-well plate polystyrene (Costar 3595; Corning Inc., Corning, NY). Briefly, $20 \mu$ of centrifuged saliva samples and $200 \mu 1$ bacterial suspension were added into the 96-well plate polystyrene using micropipettes. After inoculation, the plates were incubated at $37^{\circ} \mathrm{C}$ for 24 hours.

\section{Crystal violet binding assay.}

The culture medium was then decanted, and the plates were gently washed twice with $200 \mu$ of sterile PBS to remove planktonic and loosely bound cells. The adherent bacteria were stained with $100 \mu 10.1 \%$ crystal violet for 15 minutes. After rinsing once with $200 \mu \mathrm{l}$ of sterile PBS, the bound dye was extracted from the stained cells using $200 \mu \mathrm{l}$ of $99 \%$ ethanol. Biofilm formation was quantified by measuring the absorbance of the solution at $655 \mathrm{~nm}$ in a spectrophotometer.

\section{Results}

Table 1: Mean of optical density (OD) from biofilm assay without autolog saliva

\begin{tabular}{llc}
\hline \multicolumn{1}{c}{ Group } & N & Mean \pm SD \\
\hline Caries subjects & 15 & $0.198933 \pm 0.1477390$ \\
Caries-free subjects & 15 & $0.163433 \pm 0.1263914$ \\
$\mathrm{p}=0.983$ & & \\
*Statistically not significant from baseline $(\mathrm{p}>0.05)$
\end{tabular}

Table 2: Mean of optical density (OD) from biofilm assay with autolog saliva

\begin{tabular}{lcc}
\hline \multicolumn{1}{c}{ Group } & N & Mean \pm SD \\
\hline Caries subjects & 15 & $0.264933 \pm 0.0671879$ \\
Caries-free subjects & 15 & $0.258967 \pm 0.0511620$ \\
$\mathrm{p}=0.934$ & & \\
\hline
\end{tabular}

*Statistically not significant from baseline $(\mathrm{p}>0.05)$

\section{Discussion}

This study showed differences between $S$. mutans biofilm formation isolated from caries and caries-free subjects with or without autolog saliva although the differences are not statistically significant. The $S$. mutans isolated from the caries subjects tends to have higher biofilm formation and the autolog saliva influences the formation of biofilm. Some studies showed that $S$. mutans isolated from caries subjects produces more water-insoluble glucans without significant difference between the adhesion of $S$. mutans isolated from caries and caries-free subjects on the glass surface. ${ }^{11,12}$

The adherence of $S$. mutans to the tooth surface is influenced by 3 different antigens, which are Antigen I/ II, Glucosyltransferase and Glucan-binding protein. In early phase of biofilm formation, at least there are 30 proteins being expressed. ${ }^{3}$ First, the expression of Antigen I/II plays role as an adhesin for the salivary agglutinin increases. ${ }^{13}$ A study by Castro, Tovar and Jaramillo (2006) showed that the salivary proteins from caries subjects facilitates higher adherence of $S$. mutans, ${ }^{14}$ that is why the use of autolog saliva in this study increases the $S$. mutans biofilm formation. But on the other hand, the presence of the saliva may also diminish retention of the biofilm by decreasing the surface free energy of the underlying material. ${ }^{15}$ A study by Ahn et al (2008) showed that in the absence of sucrose, both fluid phase and adsorbed salivary preparations significantly decreased the $S$. mutans biofilm formation. ${ }^{16}$ 
Besides the sucrose-independent adherence facilitates by the salivary agglutinin, the adherence of $S$. mutans is also helped by glucans synthesized from sucrose by Glucosyltransferase. A study by Napimoga et al (2004) showed that $S$. mutans isolated from caries subjects has more genotypes than the caries-free subjects. S. mutans isolated from the caries subjects produces more waterinsoluble glucans but the adherences of $S$. mutans in the sucrose-containing medium are not significantly different. Although genotypes of $S$. mutans isolated from the cariesfree subjects produces less water-insoluble glucans, the adherence of $S$. mutans to the tooth surface was high, ${ }^{12}$ caused by the role of glucan-binding proteins. ${ }^{17}$

The presence of sucrose in the trypticase yeast medium in this study also influences the results. Sucrose is the most cariogenic carbohydrate that can be fermented and functioned as a substrate for glucans synthesis by glucosyltransferase. ${ }^{18}$ A study by Brown et al (2005) showed that carbohydrate supplementation to the growth medium increased the biofilm formation on the abiotic surface. ${ }^{19}$ A study by Ahn et al (2008) showed that biofilm forming capacities that were inhibited by salivary preparations were markedly restored when sucrose was used as a carbohydrate source. ${ }^{16}$ There are factors that may influence the result of this study, bacterial contamination, temperature and $\mathrm{pH}$. A study by Hostacka et al (2010) showed that temperature and $\mathrm{pH}$ influence the biofilm formation.

\section{Conclusion}

Autolog saliva affect the $S$. mutans biofilm formation. A tendency of higher biofilm formation of $S$. mutans isolated from caries subjects compared to those isolated from free caries subjects could be detected.

\section{References:}

1. Smith DJ. Dental Caries Vaccines: Prospects and Concerns. Crit Rev Oral Biol Med. 2002;13(4):33549.

2. Marsh PD. Dental Plaque as a Microbial Biofilm. Caries Res. 2004;38:204-11.

3. Marsh PD, Martin MV. Dental Plaque. Oral Microbiology. 5 ed. Edinburgh: Elsevier; 2009. p. 75-102.

4. Marsh PD, Martin MV. Plaque-mediated Disease - Dental Caries and Periodontal Disease. Oral Microbiology. Edinburgh: Elsevier; 2009. p. 104-17.

5. Samaranayake L. Streptococci, Staphylococci, and Micrococci. Essential Microbiology for Dentistry. 3 ed. Philadelphia: Churchill Livingstone; 2006. p.
115-8.

6. Silva ACBd, Cruz JdS, Sampaio FC, Araujo DAMd. Detection of Oral Streptococci in Dental Biofilm from Caries-Active and Caries-Free Children. Braz J Microbiol. 2008;39:648-51.

7. Banas JA, Vickerman MM. Glucan-Binding Proteins of the Oral Streptococci. Crit Rev Oral Biol Med. 2003;14(2):89-99.

8. Napimoga MH, Hofling JF, Klein MI, Kamiya RU, Goncalves RB. Transmission, Diversity, and Virulence Factors of Streptococcus mutans Genotypes. J Oral Sci. 2005;47(2):59-64.

9. Kruger C. Passive Immunization Against Oral Pathogens. Stockholm: Karolinska Institutet; 2004.

10. Banas JA. Virulence Properties of Streptococcus mutans. Front Biosci. 2004;9:1267-77.

11. Khoo G, Zhan L, Hoover C, Featherstone JDB. Cariogenic Virulence Characteristics of Mutans Streptococci Isolated from Caries-Active and CariesFree Adults. CDA Journal. 2005;33(12):973-80.

12. Napimoga MH, Kamiya RU, Rosa RT, Rosa EAR, Hofling JF, Mattos-Graner RdO, et al. Genotypic Diversity and Virulence Traits of Streptococcus mutans in Caries-Free and Caries Active Individuals. J Med Microbiol. 2004;53:697-703.

13. Bikker FJ. Salivary Agglutinin: Structure and Function. Amsterdam: University of Amsterdam; 2004.

14. Castro P, Tovar JA, Jaramillo L. Adhesion of Streptococcus mutans to Salivary Proteins in CariesFree and Caries-Susceptible Individuals. Acta Odontol Latinoam. 2006;19(2):59-66.

15. Weerkam AH, Mei HCvd, Buscher HJ. The Surface Free Energy of Oral Streptococci After Being Coated with Saliva and Its Relation to Adhesion in the Mouth. J Dent Res. 1985;64(10):1204-10.

16. Ahn S-J, Ahn S-J, Wen ZT, Brady LJ, Burne RA. Characteristics of Biofilm Formation by Streptococcus mutans in the Presence of Saliva. Infect Immun. 2008;76(9):4259-68.

17. Mattos-Graner RO, Jin S, King WF, Chen T, Smith DJ, Duncan MJ. Cloning of the Streptococcus mutans Gene Encoding Glucan Binding Protein B and Analysis of Genetic Diversity and Protein Production in Clinical Isolates. Infect Immun. 2001;69(11): 6931-41.

18. Bowen WH. Do We Need to be Concerned about Dental Caries in the Coming Millenium? Crit Rev Oral Biol Med. 2002;13(2):126-31.

19. Brown TA, Ahn S-J, Frank RN, Chen Y-YM, Lemos JA, Burne RA. A Hypothetical Protein of Streptococcus mutans is Critical for Biofilm Formation. Infect Immun. 2005;73(5):3147-51. 
